\title{
Impact of social and economic exchanges on hotel employees' job dedication and turnover intention
}

\author{
Ali Dalgıç ${ }^{1}$, Yılmaz Akgündüz
}

\begin{abstract}
The primary aim of this research is to the effect of the perceptions of hotel employees' social and economic exchange on their job dedication and turnover intention. It is also aimed to determine the effect of hotel employees' turnover intention on their job dedication in this research. In this context, questionnaire form was applied in January-March 2018 with convenience sampling method and 401 valid questionnaire forms were obtained. The validity of the scales was determined by exploratory factor analysis and their reliability was determined by Cronbach alpha values. It was found out in consequence of testing the hypotheses that social exchange increased job dedication and reduced turnover intention; economic exchange only increased turnover intention; turnover intention reduced job dedication. In this context, it can be suggested that hotel managers make positive changes in perceived social exchange in order to increase their willingness to work, such as job dedication. Another suggestion is to hotel managers make the perceived social change positive to reduce unwanted feelings and thoughts, such as turnover intention.
\end{abstract}

Keywords: Social exchange, economic exchange, job dedication, turnover intention

\section{Sosyal ve ekonomik değişimin otel çalışanlarının işe adanmışlık ve işten ayrılma niyetine etkisi}

\begin{abstract}
$\ddot{O} z$
Bu araştırmanın öncelikli amacı otel işletmelerinde çalışanların sosyal ve ekonomik değişim algılarının işe adanmışlıklarına ve işten ayrılma niyetlerine etkisini belirlemektedir. Ayrıca bu araştırmada işten ayrılma niyetinin çalışanların işe adanmışlıkları üzerindeki etkisinin de tespit edilmesi amaçlanmaktadır. Bu kapsamda oluşturulan bir anket formu Antalya'da faaliyet gösteren 5 ylldızlı otel işletmelerinde çalı̧̧an işgörenlere kolayda örnekleme yöntemiyle Ocak-Mart 2018 döneminde uygulanmış ve 401 geçerli anket formu elde edilmiştir. Yararlanılan ölçeklerin geçerlilikleri keşfedici faktör analizi, güvenirlikleri ise Cronbach alfa değerlerine bağlı olarak belirlenmiştir. Önerilen hipotezleri test etmek için yapılan regresyon analizleri sonucunda sosyal değişimin işe adanmışlı̆̆ artırdı̆̆l, işsten ayrllma niyetini azalttığı; ekonomik değişimin sadece işsten ayrılma niyetini artırdığl; işten ayrllma niyetinin ise işe adanmışlı̆̆ azalttı̆̆ belirlenmiştir. Bu kapsamda otel yöneticilerinin işgörenlerin işe adanmışlı gibi istendik tutumlarını artırmak için algılanan sosyal değişimi; işten ayrlma niyeti gibi istenmedik duygu ve düşünceleri azaltmak için algılanan sosyal değişimi pozitif hale getirmeleri önerilebilir.
\end{abstract}

Anahtar Kelimeler: Sosyal değişim, ekonomik değişim, işe adanmışlık, işten ayrllma niyeti

$\begin{array}{ll}\text { Geliş Tarihi } & : 27.09 .2018 \\ \text { Kabul Tarihi } & : 01.03 .2019\end{array}$

Alıntı için: Dalgıç, A., Akgündüz, Y. (2019). Sosyal ve ekonomik değişimin otel çalışanlarının işe adanmışlık ve işten ayrılma niyetine etkisi. Journal of Tourism Theory and Research, 5(2), 75-85.

\footnotetext{
${ }^{1}$ Sorumlu Yazar, Arş. Gör. Dr., Mersin Üniversitesi, Mersin, Türkiye

${ }^{2}$ Doç. Dr., Dokuz Eylül Üniversitesi, İzmir/Türkiye, yilmazakgunduz@hotmail.com 


\section{Giriș}

Emek-yoğun bir sektörde faaliyet gösteren turizm işletmelerinde insan unsuru ön plana çıkmaktadır. Hizmet sunan işletmeler olan turizm işletmelerinde hizmeti alan ve hizmeti verenin insan olmasından dolayı iletişim ve etkileşim önemlidir. Turizm işletmelerinde çalışanların birbirleriyle ve yönetimle olan olumlu ilişkisi, iletişimi ve etkileşimi kuvvetlendirmektedir (Jeong ve Oh, 2017: 116). Bu durumu sosyal değişim kuramıyla açıklamak mümkündür. Sosyal değişim kuramı, bireyler arası güvene dayanan ve karşıl1klı sosyo-duygusal değişimlerin meydana gelmesi sonucunda çalışanların olumlu çıktılar meydana getirebileceğini savunur (Emerson, 1981: 35). İşletmedeki sosyal değişim düzeyinin artmasıyla birlikte çalışanların işe adanmışlık düzeylerinin artacağı (Li, Sanders ve Frenkel, 2012; Liao, Yang, Wang, Drown ve Shi, 2013) ve işten ayrılma niyetlerinin azalacağ 1 (Shore, Bommer, Rao ve Seo, 2009; Loi, Mao ve Ngo, 2009) belirtilebilir. Diğer bir değişim türü olan ekonomik değişimde ise sosyal değişimin aksine kısa vadede dönüş isteği, belirli vaadler ve ekonomik kaynaklar söz konusudur (Jiwen Song, Tsui ve Law, 2009: 57). Değişim içerisinde maddi kaynakların yer alması, sosyal değişimin aksine güven duygusu yerine belirli vaadlere dayanması ve kısa vadede geridönüş beklentisi, diğer farklı ekonomik getirisi olan beklentiler (ikramiye, terfi vb.) nedeniyle çalışanlar açısından olumsuz çıktılara neden olabilmektedir. $\mathrm{Bu}$ nedenle ekonomik değişim sosyal değişimin aksine çalışanların işe adanmışlıklarını azalttığı (Greene, 2012) ve işten ayrılma niyetlerini arttırdığı (Shore, Bommer, Rao ve Seo, 2009; Loi, Mao ve Ngo, 2009) belirtilebilir.

Turizm işletmelerinde hizmet sunum sürecinin aksamaması için işgören devir hızının azaltılması gerekmektedir. Kalifiye işgörenlerin işletmede tutulması, işi bilen ve işletmeyi tanıyan işgörenlerle operasyonların yürütülmesi, müșteri memnuniyetin sürdürülmesi gibi sebepler çalışanların işten ayrılma niyetlerini azaltmanın önemine işaret etmektedir. Ayrıca, işten ayrılan çalışanın yerine yeni bir çalışan bulunması, oryantasyon süreci ve eğitim masrafları, işletmede yapacağ 1 iş hataları işletmeye birer maliyet olarak yansımaktadır (Yang, 2008: 433). İșten ayrılmaları azaltabilmek için çalışanların iş yaşamlarında mutlu olmaları önemlidir. Çalışanlara sosyal ilişkiler yanında işletme açısından önemli olduklarını hissettirmek, çalışanlara geribildirim vermek önemli hususlardır. Böylelikle çalışanlarının işlerine daha çok bağlanmaları ve adanmaları sağlanabilir. İşlerine adanan ve örgüte bağlanan çalışanlar, işlerine ve sorumluluklarına odaklanarak olumsuz düşüncelerini azaltabileceklerdir. Diğer bir ifadeyle, işe bağlanan çalışanın işten ayrılma niyeti azalacaktır (Van Scotter ve Motowidlo, 1996; Van Scotter, 2000).

$\mathrm{Bu}$ çalışmada, Antalya'da faaliyet gösteren 5 yıldızlı otel çalışanlarının işletmedeki sosyal ve ekonomik değişim algılarının işe adanmışlıkları ve işten ayrılma niyetlerini nasıl etkilediği araştırılmıştır. Çalışmada öncelikli olarak değişkenlerle (sosyal değişim, ekonomik değişim, işe adanmışlık ve işten ayrılma niyeti) ilgili literatür taramasına yer verilmiştir. Devamında araştırma hipotezlerinin gerekçeleri ve araştırma yöntemi sunulmuştur. Toplanan verilerin analiz sonuçları detaylı olarak bulgular kısmında sunularak çalışma, sonuç ve öneriler bölümüyle tamamlanmıştır.

\section{Literatür ve hipotezler}

\subsection{Sosyal ve ekonomik değişim}

Bireyler arası etkileşimi sosyal ve ekonomik değişim olarak ikiye ayırmak mümkündür. Sosyal değişim, karşıllılı güvene dayanan ve sosyo-duygusal (socia-emotinal) kaynakların değişimini içeren değişim türüdür (Jiwen Song, Tsui ve Law, 2009: 57). Sosyal değişimin temelinde kişiler arası güven, belirli konularda karşılıklı değişim ve bazı yükümlülükler söz konusudur (Emerson, 1981: 35). Sosyal değişimde, bireyler arası değişimin ne zaman gerçekleşeceği belirsiz olmasına karşın karşıllıklı güvene dayanan ilişkilerle yapılan iyiliğin geridönüşü süre kısıdı olmadan beklenir (Blau, 1964). Ekonomik değişim ise, belirli vaadlere ve sözleşmelere dayanan ekonomik değişimleri içermektedir (JiwenSong, Tsui ve Law, 2009: 57). Diğer bir ifadeyle ekonomik değişimde, bireyler arası karşılıklı belirli işlemlere (transactions) ve ekonomik değişimlere de ihtiyaç duyulmaktadır (Shore, Tetrick, Lynch ve Barksdale, 2006: 839). Sosyal değişimdeki ilișkisel sözleşmelerden farklı olarak ekonomik değişimde işlemsel sözleşmeler 
(transactional contracts) mevcuttur (Konovsky ve Pugh, 1994: 658).

Turizm işletmelerinde hizmetin başarılı bir şekilde yerine getirilebilmesi için çalışanların birbirleriyle olan etkileşimi ve iletişimi önemlidir. Müşteri isteklerinin hızlı ve tam olarak yerine getirilebilmesi için birbirleriyle koordine çalışan işgörenlerin örgütte bulunması gerekmektedir. $\mathrm{Bu}$, çalışanların sosyal değişimleriyle mümkün olabilmektedir (GouldWilliams ve Davies, 2005: 4). İşletmede, sosyal değişim yerine ekonomik değişimin ön planda olması hem çalışanlar hem de örgüt için olumsuz sonuçları beraberinde getirebilir. Belirli sözleşmelere dayanan ve sadece ekonomik kaynakların değişimini kapsayan ekonomik değişim iletişim/etkileşim sorunu ve hizmette kalitenin düşmesi gibi problemler ortaya çıkarabilmektedir (Loi, Mao ve Ngo, 2009: 404).

İlgili alanyazında yapılan çalışmalarda, sosyal değişimin örgütsel vatandaşlık davranışı (Konovsky ve Pugh, 1994; Jiwen Song, Tsui ve Law, 2009), örgütsel bağl1l1k (Shore, Tetrick, Lynch ve Barksdale, 2006; Lavelle, Rupp ve Brockner, 2007; Shore, Bommer, Rao ve Seo, 2009; Loi, Mao ve Ngo, 2009), iş performans1 (Jiwen Song, Tsui ve Law, 2009), algılanan örgütsel destek (Shore, Tetrick, Lynch ve Barksdale, 2006) ile pozitif yönlü ilişkisinin olduğu tespit edilmiştir. Ayrıca, sosyal değişim işletme çalışanlarının işten ayrılma niyetlerini de azaltmaktadir (Shore, Bommer, Rao ve Seo, 2009; Loi, Mao ve Ngo, 2009). Ekonomik değişim ise işletme çalışanları için örgütte istenmedik/olumsuz çıktılara sebep olabilmektedir. Ekonomik değişimin, örgütsel bağl1lık (Shore, Tetrick, Lynch ve Barksdale, 2006; Loi, Mao ve Ngo, 2009; Shore, Bommer, Rao ve Seo, 2009), iş performansı (Jiwen Song, Tsui ve Law, 2009), örgütsel vatandaşlık davranışı (Jiwen Song, Tsui ve Law, 2009), algılanan örgütsel destek (Shore, Tetrick, Lynch ve Barksdale, 2006) ile negatif ilişkili olduğu yapılan çalışmalarda belirlenmiştir. Ayrıca ekonomik değişimin işletme çalışanlarının işten ayrılma niyetlerini artırdığ $\breve{ }_{1}$ da belirlenmiştir (Shore, Bommer, Rao ve Seo, 2009; Loi, Mao ve Ngo, 2009).

\section{2. İşe adanmışlık}

İşe adanmışlık, bir işletme çalışanın sorumlu olduğu işleri yerine getirirken istekli bir şekilde ekstra performans ortaya koyma durumudur. İşe adanmışl1k, bir çalışanın işlerini eksiksiz yerine getirmesi ve işleri dışında da ekstra performans ortaya koymasını ifade etmektedir (Harzer ve Ruch, 2014: 187). İşe adanmışlık derecesi, işin çalışan bireye yüklemiş olduğu psikolojik kimlik ve işin imajıyla ilgili tutumla doğru orantılı olarak artış göstermektedir (Lodahl ve Kejner, 1965). İşe adanmışlık derecesi yüksek olan çalışanlar, işletme içerisindeki kurallara uymak, sorumluluklarını yerine getirmek için daha fazla çaba sarf etmektedirler (Van Scotter ve Motowidlo, 1996: 526). Bunlara ek olarak işe adanmışlık, çalışanların iyi oluş düzeyini de arttırmaktadır (Lee, Choo ve Hyun, 2016: 3). Emek-yoğun bir sektörde faaliyet gösteren turizm işletmeleri açısından ele alındığında, işe adanmış çalışanlar müşteri memnuniyetini arttıracaktır (Karatepe ve Olugbade, 2009: 511). Turizm işletmelerinde çalışan bireylerin işe adanmışlık seviyelerinin yükselmesiyle iş bilgileri ve iş performanslarında artış meydana gelecektir (Van Scotter ve Motowidlo, 1996: 526). Ayrıca, işe adanmışlıkları artan çalışanların örgütsel bağl11ıkları artacak (Molina, Gonzalez, Florencio ve Gonzalez, 2014), işten ayrılma niyetleri azalacaktır (Van Scotter, 2000).

\subsection{Isşten ayrılma niyeti}

İşten ayrılma niyeti, bir çalışanda işletmeden ayrılma düşüncesinin oluşması ve çalışanın alternatif iş olanaklarını incelemesi durumu, işletme ile olan bağ 1 koparmadaki son adımlardan biri olarak tanımlanabilir (Tett ve Meyer, 1993: 262). Mobley (1977) işten ayrılma niyetini, bazı psikolojik adımların (mevcut işin değerlendirilmesi, mevcut işten memnun olmama durumunun ortaya çıkışı, ayrılma düşüncesi, ayrılma maliyetlerinin değerlendirilmesi, ayrılma durumunda başvurulabilecek işletmelerin değerlendirilmesi, mevcut iş ile yeni bulunan işin kıyaslanması, kalma ya da ayrilma durumu) sonucunda bireylerin geri çekilmedeki karar süreci olarak belirtmiştir. İşten ayrılma niyeti sonucunda, işletme çalışanının ayrılma kararı vermesiyle birlikte işletme açısından tecrübeli çalışan kaybının yanı sıra işten ayrılan kişinin yerini doldurmak için bir dizi maliyete katlanma zorunluluğu ortaya çıkarmaktadır (Yang, 2008: 433).

Turizm işletmeleri açısından düşünüldüğünde, emek-yoğun bir sektör için işten ayrılma niyetinin önemli bir konu olduğu belirtilebilir. İșten ayrılmaların fazla olduğu bu sektörde, müşterilere kaliteli hizmet 
sunmak, müşterilerle iyi etkin iletişim kurmak, müşterileri memnun etmek gibi kritik konularda sorun yaşanabilmektedir. Kalifiye personel bulma, yeni personele eğitim verilmesi, para ve zaman kaybı gibi durumlardan dolayı mevcut personeli elde tutma çabaları turizm işletmeleri açısından önem arz etmektedir (Choi, 2006: 322). Bunlara ek olarak, işletmelerin operasyonel faaliyetlerinde bazı aksaklıklar ve stratejik rekabet avantajını kaybetme riskleri de ortaya çıkabilir (Tracey ve Hinkin, 2008: 14). Yapılan araştırmalara göre, işten ayrılma niyetini arttıran en önemli hususlar iş tatminsizliğinin meydana gelmesi ve örgüte bağl1lı̆̆ın azalmasıdır (Choi, 2006; Yang, 2008).

\subsection{Hipotezlerin geliştirilmesi}

Sosyal değişim teorisi, bireylerarası basit değişimlere dayalı etkileşimlere göre tutum ve davranışların şekilleneceğini savunur (Blau, 1964). Bu teori etkileşim ve iletişim içerisinde olan grupların tesadüfen meydana gelmediğini, karşılıklı değişimler sonucunda oluştuğunu ileri sürmektedir (Homans, 1961: 13). Sosyal değişimde saygı, arkadaşlık, önemseme gibi soyut sosyal maliyetler ve yararlar mevcuttur (Gefen ve Ridings, 2002: 50). Sosyal değişimin yüksek ve güçlü olduğu işletmelerde işgörenler, sorumluluklarını yerine getirme duygularıyla çalışmaktadırlar. $\mathrm{Bu}$ çalışanlar, çoğu zaman da kendi sorumluluklarının üzerinde/ötesinde örgüte daha fazla katkı sağlamaya çalışmaktadırlar (Shore, Tetrick, Lynch ve Barksdale, 2006: 845). Bu durumda sosyal değişimin çalışanların işe adanmışlıklarını üzerinde pozitif bir etkiye sahip olduğu söylenebilir. Yapılan çalışmalarda da sosyal değişimin çalışanların işe adanmışlıkları üzerinde pozitif bir etkiye sahip olduğu görülmüştür $(\mathrm{Li}$, Sanders ve Frenkel, 2012; Liao, Yang, Wang, Drown ve Shi, 2013; Agarwal, 2014). Ayrica, sosyal değişimin çalışanların işten ayrılma niyetlerini de azalttığ 1 yapılan araştırmalarda bulgulanmıştır (Shore, Bommer, Rao ve Seo, 2009; Loi, Mao ve Ngo, 2009). Sosyal değişim teorisi ve yapılan çalışma sonuçlarına bağlı olarak $\mathrm{H} 1$ ve $\mathrm{H} 2$ geliştirilmiştir:

H1. Sosyal değişim, çalışanların işe adanmışlık düzeylerini artırıcı etkiye sahiptir.

H2. Sosyal değişim, çalışanların işten ayrılma niyetlerini azaltıcı etkiye sahiptir.
Ekonomik değişim teorisine göre işletme çalışanları uzun vadeli ve açık uçlu değişim beklentisinde değildir ve ekonomik anlaşmalar yaparak belirli değişimleri gerçekleştirmek istemektedirler. Kısa vadeli finansal yükümlülükler ve çalışanların ekonomik beklentileri, çalışanların davranışlarını biçimlendirmektedir (Shore, Tetrick, Lynch ve Barksdale, 2006: 839). İşletme çalışanları yaptıkları işlerden parasal ödül, promosyon gibi dışsal faydalar elde edeceklerine inanıyorlarsa örgüt için çalışmaya devam ederler (Bock ve Kim, 2002: 15). İşletme çalışanlarının ekonomik değişimlerinin süresinin artması, ekonomik değişimlerde oluşan azalma, ekonomik değişimlerin beklentileri karşılamaması gibi hususlar örgüt çalışanın performansını ve davranışını olumsuz olarak etkilemektedir (Shore, Tetrick, Lynch ve Barksdale, 2006: 846). Greene (2012), tarafindan ekonomik değişim ile işletme çalışanlarının işe adanmışlıkları arasında negatif bir ilişki olduğu bulgulanmıştır. Buna ek olarak, ekonomik değişimin çalışanların işten ayrılma niyetlerini arttığ yapılan araştırmalarda bulgulanmıştır (Shore, Bommer, Rao ve Seo, 2009; Loi, Mao ve Ngo, 2009). Ekonomik değişim teorisi ve ilgili çalışma sonuçları dikkate alınarak $\mathrm{H} 3$ ve $\mathrm{H} 4$ geliştirilmiştir:

H3. Ekonomik değişim, çalışanların işe adanmışlık düzeylerini azaltıcı etkiye sahiptir.

H4. Ekonomik değişim, çalışanların işten ayrılma niyetlerini artırıcı etkiye sahiptir.

İşle bütünleşme teorisi (work engagement theory), işletme çalışanlarının pozitif enerjileriyle ne kadar çok çalışırlarsa, işten ayrılma niyetlerinin o kadar az olacağını belirtmektedir (Saks, 2006: 602). Diğer bir ifadeyle, bir işletmede psikolojik ve duygusal olarak meşgul olan çalışanlar, işten ayrılma niyetini tetikleyen stres ve yorgunluğu daha az yaşamaktadırlar (Kahn, 1990: 700). Bu teoriye göre, çalışanların işi çekici bulması ve işlerine adanmaları çalıştıkları işletmede kalmalarını sağlayacaktır. Böylelikle, işine adanan bireylerin işten ayrılma niyetleri azalacaktır (Saks, 2006: 602-603). İşten ayrılma niyetine sahip çalışanların işlerine daha az adanacaklarını da söylemek mümkündür. Yapılan çalışmalarda da işten ayrılma niyetinin işe adanmışlık üzerinde negatif yönlü bir etkiye sahip olduğu bulgulanmıştır (Van Scotter, 2000; Bhatnagar, 2012; Dane ve Brummel, 2013; Micheal, 2014; Meng ve Han, 2014). İşle bütünleşme 
teorisi ve yapılan araştırmaların sonuçlarına bağlı olarak H5 önerilmiştir:

H5. Çalışanların, işten ayrılma niyetleri işe adanmışlıklarını azaltmaktadır.

\section{Yöntem}

Veriler Antalya'da faaliyet gösteren 5 y1ldızlı otel çalışanlarından anket formu ile toplanmıştır. Ankette yer alan ölçeklerin, işten ayrılma niyeti ölçeği hariç, maddeleri İngilizce'den Türkçe'ye çevrilmiş ve akademik uzman yardımıyla anketin kalitesinin sağlanması için ölçek maddeleri tekrardan İngilizce'ye çevrilmiştir (Brislin, 1970). Toplamda 500 anket formu, 5 yıldızlı 4 otele dağıtılmıştır. Çalışanlardan sosyal değişim, ekonomik değişim, iş adanmışlık ve işten ayrılma niyeti algılarıla ilgili soruları yanıtlamaları istenmiştir. Dağıtılan 500 anketten 416 tanesinin geridönüşü olmuştur. $\mathrm{Bu}$ anket formlarından 401'inin kullanılabilir olduğu belirlenmiştir. Buna göre anket geridönüş oranının \% 83 olduğu söylenebilir.

$\mathrm{Bu}$ çalışmada standart ölçekler kullanılmış ve 5'li Likert ölçeğinde bir formda ölçülmüştür $(1=$ Kesinlikle Katılmıyorum 5 = Kesinlikle Katılıyorum).
Çalışanların sosyal ve ekonomik değişime ilişkin görüşleri Shore, Tetrick, Lynch ve Barksdale (2006) tarafından geliştirilmiş olan 16 maddelik ölçek kullanılarak belirlenmiştir. Sosyal değişim ölçeğinin güvenilirliği 0,96 , ekonomik değişim ölçeğinin ise 0,91'dir. Çalışanların kendi işe adanmışlıklarına ilişkin görüssleri Lee, Choo ve Hyun (2016) tarafindan kullanılan 7 maddelik ölçek kullanılarak belirlenmiştir. $\mathrm{Bu}$ ölçeğin güvenilirliği 0,90 'dır. Son olarak, çalışanların işten ayrılma niyetleri Akgündüz ve Akdağ (2014) tarafindan kullanılan 4 maddelik ölçek ile belirlenmiştir. Bu ölçeğin güvenilirliği ise 0.97 'dir.

\section{Bulgular}

Araştırmaya katılan otel çalışanlarının \%65'i (260 kişi) erkek ve \%52'si (194 kişi) üniversite mezunudur. Katılımcıların \%61'i (219 kişi) sezonluk iş statüsünde olup \%51'i (178 kişi) 18-24 yaş aralığındadır. Bunlara ek olarak, otel çalışanlarının \%93'ünün (263 kişi) 1-5 yıl arasında aynı işletmede çalıştı̆̆ ve \%55'inin (104 kişi) 1-5 yıl arasında iş deneyimine sahip olduğu belirtilebilir. Tablo 1'de katılımcıların özellikleri detaylı olarak verilmiştir.

Tablo 1. Kat1lımc1ların özellikleri

\begin{tabular}{|c|c|c|c|c|c|}
\hline Cinsiyet & $\mathrm{n}$ & $\%$ & Yaș & $\mathrm{N}$ & $\%$ \\
\hline Kadın & 141 & 35 & $18-24$ yaş & 178 & 51 \\
\hline Erkek & 260 & 65 & 25-34 yaş & 150 & 43 \\
\hline Eğitim & & & 35 yaş ve üzeri & 21 & 6 \\
\hline İlkokul & 4 & 1 & İşletmedeki Deneyim & & \\
\hline Ortaokul & 3 & 1 & $1-5$ y1l & 263 & 93 \\
\hline Lise & 170 & 46 & $6-10$ y1l & 21 & 7 \\
\hline Üniversite & 194 & 52 & İş Tecrübesi & & \\
\hline İş Statüsü & & & $1-5 \mathrm{y} 11$ & 104 & 55 \\
\hline Sezonluk & 219 & 61 & 6 yıl ve üzeri & 84 & 45 \\
\hline Tüm Yıl & 141 & 39 & & & \\
\hline
\end{tabular}

Araştırma kapsamında yararlanılan ölçeklerin geçerliliklerini belirlemek amacıyla keşfedici faktör analizleri gerçekleştirilmiştir. Analizlerde faktör sayısının tespitinde özdeğerin 1'den büyük olmasına, ilgili faktör ile en az 0,50 düzeyinde yüke sahip olmasina (Hair, Black, Babin ve Anderson, 2010), binişiklik durumunda iki faktör arasında yük farkının en az 0,10 olmasina (Büyüköztürk, 2002) ve Varimax dönüşümü uygulanmasına karar verilmiştir.

Tablo 2'de Sosyal-Ekonomik Değişim Ölçeğine ait keşfedici faktör analizi sonuçları özetlenmiştir. Sosyal-
Ekonomik Değişim Ölçeğinin KMO değeri 0,950 olarak bulgulanmıştır. Buna ek olarak, Bartlett Küresellik testi sonucunun anlamlı olduğu görülmüştür $\quad\left(x^{2}=6662,146 ; \quad \mathrm{p}<0,001\right)$. Belirtilen testlerin sonuçları göz önüne alındığında SosyalEkonomik Değişim Ölçeğine faktör analizi yapılmasının uygun olacağı görülmüsstür. Yapılan faktör analizi sonucunda, ölçekten yer alan iki madde analizlerden çıkarılmıştır. Geriye kalan 14 madde iki faktör altında toplanmış ve varyansın yaklaşık olarak \%78'ini açıklamıştır. 
Tablo 2. Sosyal-ekonomik değişim ölçeği açıklayıcı faktör analizi

\begin{tabular}{|c|c|c|c|c|c|}
\hline & $\begin{array}{l}\text { Faktör } \\
\text { yükü }\end{array}$ & Ortalama & Özdeğer & $\begin{array}{l}\text { Açıklanan } \\
\text { Varyans }\end{array}$ & Güvenirlik \\
\hline 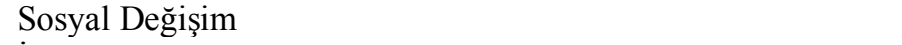 & & 3,633 & 6,614 & 47,241 & 974 \\
\hline $\begin{array}{l}\text { İşteki başarım, uzun vadede bu oteldeki konumumun } \\
\text { belirlenmesinde etkili olacaktır. }\end{array}$ & ,907 & & & & \\
\hline $\begin{array}{l}\text { Otel ile olan ilişkimde özveride bulunduğum ve elde ettiğim } \\
\text { birçok şey vardır. }\end{array}$ & ,905 & & & & \\
\hline $\begin{array}{l}\text { Bugün çok çalışmış olmamı umursamıyorum. Eninde sonunda } \\
\text { otel tarafından ödüllendirileceğimi biliyorum. }\end{array}$ & ,903 & & & & \\
\hline $\begin{array}{l}\text { Çalıştı̆̆ım otelin benimle ilgilendiğini bildiğim için otelin } \\
\text { çıarlarını korumaya çalışırım. }\end{array}$ & ,891 & & & & \\
\hline Çalıştı̆̆ım otel ile ilişkim karşılıklı güvene dayanır. & 891 & & & & \\
\hline $\begin{array}{l}\text { Genellikle hak ettiğimi otelden almadığımı bilsem bile, } \\
\text { çabalarımın gelecekte ödüllendirileceğini bilirim. }\end{array}$ & ,882 & & & & \\
\hline Cabalarımın hiçbir zaman ödüllendirilmeyeceğini biliyorum. & ,874 & & & & \\
\hline Çalıştığım otel bana önemli bir yatırım yapıyor. & 684 & & & & \\
\hline Ekonomik Değişim & & 3,176 & 4,307 & 30,762 & 891 \\
\hline $\begin{array}{l}\text { Aldığım ücret ve diğer kazanımlara gösterdiğim çaba eşit } \\
\text { düzeydedir. }\end{array}$ & ,837 & & & & \\
\hline $\begin{array}{l}\text { Çalışma durumumu en doğru şöyle tanımlayabilirim: Bir } \\
\text { günlük adil bir ödeme için, ücretin karşıllğı kadar çalışıyorum. }\end{array}$ & ,833 & & & & \\
\hline Maaşım ödendiği için, otelin gerektirdiği işleri yapıyorum. & ,791 & & & & \\
\hline $\begin{array}{l}\text { Aldığım ücrete ve diğer kazanımlara eşit düzeyde } \\
\text { çalışıyorum. }\end{array}$ & ,777 & & & & \\
\hline $\begin{array}{l}\text { İşletme ile olan ilişkim kesinlikle ekonomik bir boyuttadır: } \\
\text { Çalışyorum ve bunun karşılığında ödeme yapıyorlar. }\end{array}$ & ,725 & & & & \\
\hline $\begin{array}{l}\text { Otele ne kadar katkıda bulunduğumu ve ne kadar kazanım } \\
\text { (maaș ve ekstra ücret) elde ettiğimi dikkatli bir șekilde izlerim. }\end{array}$ & ,673 & & & & \\
\hline
\end{tabular}

Tablo 3. İşe adanmışılık ölçeği açıklayıcı faktör analizi

\begin{tabular}{|c|c|c|c|c|c|}
\hline & $\begin{array}{c}\text { Faktör } \\
\text { yükü }\end{array}$ & Ortalama & Özdeğer & $\begin{array}{c}\text { Açıklanan } \\
\text { Varyans }\end{array}$ & Güvenirlik \\
\hline İşe Adanmışlık & & 4,107 & 4,596 & 65,651 & 890 \\
\hline Zor görevleri severim. &, 850 & & & & \\
\hline $\begin{array}{l}\text { Görevimi tamamlamak için zorluklarla baş etmeye } \\
\text { çalışırım. }\end{array}$ & 849 & & & & \\
\hline İșlerimi tamamlamak için fazladan mesai yaparım. & ,814 & & & & \\
\hline Gerekenden fazla çalıșırım. & 804 & & & & \\
\hline Zor görevlerin hevesle üstesinden gelirim. & 803 & & & & \\
\hline İșimde önemli ayrıntılara dikkat ederim. & 802 & & & & \\
\hline Disiplinliyimdir, kendimi kontrol ederim. &, 747 & & & & \\
\hline
\end{tabular}

Tablo 3'de İşe Adanmışlık Ölçeğine uygulanan keşfedici faktör analizi sonuçları özetlenmiştir. İşe Adanmışlık Ölçeğinin KMO değerinin 0,825 ve Bartlett Küresellik testi sonucunun anlamlı olduğu görülmüştür $\quad\left(\mathrm{x}^{2}=2592,359 ; \quad \mathrm{p}<0,001\right) . \quad$ Belirtilen değerler göz önüne alındığında ölçeğe açıklayıcı faktör analizi yapılmasının uygun olacağı belirlenmiştir. Analiz sonucunda 7 maddenin orijinalinde olduğu gibi tek faktör altında toplandığı belirlenmiştir.
İşten Ayrılma Niyeti Ölçeğine uygulanan keşfedici faktör analizi sonuçları Tablo 4'de verilmiştir. İşten Ayrılma Niyeti Ölçeğinin KMO değerinin 0,880 ve Bartlett Küresellik testi sonucunun anlamlı olduğu görülmüştür $\quad\left(x^{2}=2273,714 ; \quad \mathrm{p}<0,001\right)$. Belirtilen değerler göz önüne alındığında ölçeğe faktör analizi yapılmasının uygun olacağı belirlenmiştir. Yapılan faktör analizi sonucunda ölçeğin orijinalinde olduğu gibi 4 maddeden ve tek faktörden oluştuğu tespit edilmiştir. 
Tablo 4. İşten ayrılma niyeti ölçeği açıklayıcı faktör analizi

\begin{tabular}{|c|c|c|c|c|}
\hline & $\begin{array}{c}\text { Faktör } \\
\text { yükü }\end{array}$ & Ortalama Özdeğer & $\begin{array}{c}\text { Açıklanan } \\
\text { Varyans }\end{array}$ & Güvenirlik \\
\hline İşten ayrılma niyeti & & 2,256 &, 92725 & 974 \\
\hline $\begin{array}{l}\text { Bazen yaptığım işi bırakmak zorunda olduğumu } \\
\text { düşünüyorum. }\end{array}$ & 965 & & & \\
\hline $\begin{array}{l}\text { Başka bir otelde çalışmak için bu otelden ayrılmayı } \\
\text { düşünüyorum. }\end{array}$ & ,964 & & & \\
\hline Muhtemelen önümüzdeki yıl yeni bir iş arayacağım. & 963 & & & \\
\hline $\begin{array}{l}\text { Çalışma koşullarım kötüleşirse, bu otelden ayrılmayı } \\
\text { düşünüyorum. }\end{array}$ & ,960 & & & \\
\hline $\begin{array}{l}\mathrm{KMO}=, 880 \text { Barlett'sTesf of Sphericity }=2273,714 \text { Sig. }=< \\
\mathrm{F}=2,723\end{array}$ & 0017 & m Açıklanan Va & $=0,92725$ & enirlik=,974 \\
\hline
\end{tabular}

Tablo 5'de değişkenlere ait ortalama, standart sapma, Cronbach's Alpha ve ilişki değerleri verilmiştir. Sosyal değişim değişkeninin ekonomik değişim $(r=-0,640 ; p<0,001)$ ve işten ayrilma niyeti $(\mathrm{r}=-0,863 ; \mathrm{p}<0,001)$ değişkenleriyle arasında anlamlı ve negatif ilişki olduğu tespit edilmiştir. Ayrıca, sosyal değişim değişkeninin işe adanmışlık ile anlamlı ve pozitif bir ilişkiye sahip olduğu da diğer bir bulgudur $(\mathrm{r}=0,847 ; \mathrm{p}<0,001)$. Ekonomik değişim değişkeninin işe adanmışlık değişkeniyle arasında anlamlı ve negatif bir ilişki $(\mathrm{r}=-0,530 ; \mathrm{p}<0,001)$ ve işten ayrılma niyeti $(\mathrm{r}=0,709 ; \mathrm{p}<0,001)$ değişkeniyle arasında anlamlı ve pozitif bir ilişki belirlenmiştir. Son olarak, işe adanmışlık değişeniyle işten ayrılma niyeti değişkeni arasında anlamlı ve negatif bir ilişkinin olduğu görülmüştür $(\mathrm{r}=-0,771 ; \mathrm{p}<0,001)$.

Tablo 5. Değişkenlere ait ortalama, standart hata, güvenilirlik ve korelasyon analizi sonuçları

\begin{tabular}{llcccccc}
\hline & & Ortalama & St. Hata & 1 & 2 & 3 & 4 \\
\hline 1 & İşten Ayrılma Niyeti & 2,256 & 1,06 & $(, 974)^{\mathrm{a}}$ & & & \\
2 & Sosyal Değişim & 3,633 &, 97 &,$- 863^{* *}$ & $(, 974)^{\mathrm{a}}$ & & \\
3 & Ekonomik Değişim & 3,176 &, 57 &, $709^{* *}$ &,$- 640^{* *}$ & $(, 891)^{\mathrm{a}}$ & $(, 890)^{\mathrm{a}}$ \\
4 & İşe Adanmişlik & 4,107 &, 63 &,$- 771^{* *}$ &, $847^{* *}$ &,$- 530^{* *}$ & \\
\hline$* * \mathrm{p}<0.01$ (2-yönlü). a Değişkene ilişkin cronbach’ alfa değeridir. & & & \\
\hline
\end{tabular}

Sosyal ve ekonomik değişim değişkenlerinin işe adanmışlık değişkeni üzerindeki etkisini belirlemek için çoklu regresyon analizi gerçekleştirilmiştir. Analiz sonucuna göre sosyal değişimin işe adanmışlık üzerinde anlamlı ve pozitif etkisinin olduğu bulgulanmıştır $(\beta=, 556 ; p<0,01)$. Ekonomik değişmin ise işe adanmışlık üzerinde anlamlı bir etkisinin olmadığ1 görülmüştür $(\beta=, 019 ; \mathrm{p}>0.05)$. Analiz otel çalışanlarının işe adanmışlığının yaklaşık \%72'si sosyal ve ekonomik değişim değişkenleriyle açıklandığını göstermektedir. Bulgular H1 hipotezini desteklenmesine rağmen $\mathrm{H} 3$ hipotezini reddetmektedir.

Tablo 6. Değişkenlere ait regresyon analizi sonuçları

\begin{tabular}{lcccccccc}
\hline & \multicolumn{3}{c}{$\begin{array}{c}\text { Standardize Edilmemiş } \\
\text { Katsaylar }\end{array}$} & \multicolumn{2}{c}{ Standart Katsayılar } & & & \\
\cline { 2 - 5 } Değişken & $\beta$ & Std. Hata & $\beta$ & $\mathrm{t}$ & Sig. & VIF & CI \\
\cline { 2 - 5 } (Sabit) & 2,063 & 0,161 & & 12,844 &, 000 & & 1,000 \\
Sosyal Değişim &, 556 & 0,022 & 0,861 & 24,839 &, 000 & 1,694 & 5,535 \\
Ekonomik Değişim &, 019 & 0,031 & 0,021 & 0,610 &, 542 & 1,694 & 20,308 \\
\hline
\end{tabular}

$\mathrm{R}=, 847 \mathrm{R}^{2}=, 718 \Delta \mathrm{R}^{2}=, 716 \mathrm{~F}=506,341 \mathrm{Sig} .=, 000 \mathrm{D}-\mathrm{W}=2,240$; Bağımlı Değişken: İşe Adanmışlık 
Tablo 7. Değişkenlere ait regresyon analizi sonuçları

\begin{tabular}{|c|c|c|c|c|c|c|c|}
\hline \multirow[b]{2}{*}{ Değişken } & \multicolumn{2}{|c|}{$\begin{array}{c}\text { Standardize Edilmemiş } \\
\text { Katsayılar }\end{array}$} & \multicolumn{2}{|c|}{ Standart Katsayilar } & \multirow[b]{2}{*}{ Sig. } & \multirow[b]{2}{*}{ VIF } & \multirow[b]{2}{*}{$\mathrm{CI}$} \\
\hline & $\beta$ & Std. Hata & $\beta$ & $\mathrm{t}$ & & & \\
\hline (Sabit) & 2,204 & ,218 & & 10,119 & ,000 & & 1,000 \\
\hline Sosyal Değişim &,- 403 & ,035 &,- 405 & $-11,404$ & ,000 & 2,770 & 3,923 \\
\hline Ekonomik Değişim & 605 & 039 &, 547 & 15,395 &, 000 & 2,770 & 20,143 \\
\hline
\end{tabular}

Sosyal ve ekonomik değişim değişkenlerinin işten ayrılma niyeti üzerindeki etkisini belirlemek için gerçekleştirilen çoklu regresyon analizi sonuçları Tablo 7'de özetlenmiştir. Analizi sonucunda, sosyal değişmin işten ayrılma niyeti üzerinde anlamlı ve negatif etkisinin olduğu $(\beta=-, 403 ; \quad p<0,001)$ ve ekonomik değişimin işten ayrılma niyeti üzerinde anlamlı ve pozitif etkisinin olduğu $(\beta=, 605 ; p<0,01)$ belirlenmiştir. Analiz otel çalışanlarının işten ayrılma niyetlerinin yaklaşık \%82'sinin sosyal ve ekonomik değişim tarafından açıklandığını göstermektedir.
Analiz sonuçlarına bağlı olarak H2 ve H4 kabul edilmiştir.

Otel çalışanlarının işten ayrılma niyetlerinin işe adanmışlıkları üzerindeki etkisini belirlemek amacıyla gerçekleştirilen basit regresyon analizi Tablo 8'de özetlenmiştir. Analiz sonuçları işten ayrılma niyetinin çalışanların işe adanmışlıklarını azalttı̆̆ını ( $\beta=-, 692$; $\mathrm{p}<0,01)$ göstermekte ve işe adanmışlığın yaklaşık \%60'ının işten ayrılma niyeti tarafından açıklandığını göstermektedir. Analiz sonuçlarına bağlı olarak H5 kabul edilmiştir.

Tablo 8. Değişkenlere ait regresyon analizi sonuçları

\begin{tabular}{|c|c|c|c|c|c|c|c|}
\hline \multirow[b]{2}{*}{ Değişken } & \multicolumn{2}{|c|}{$\begin{array}{c}\text { Standardize Edilmemiş } \\
\text { Katsayılar }\end{array}$} & \multicolumn{2}{|c|}{ Standart Katsayılar } & \multirow{3}{*}{$\begin{array}{l}\text { Sig. } \\
, 000\end{array}$} & \multirow{3}{*}{ VIF } & \multirow[b]{2}{*}{$\mathrm{CI}$} \\
\hline & $\beta$ & Std. Hata & $\beta$ & $\mathrm{t}$ & & & \\
\hline (Sabit) & 5,372 & ,072 & & 75,114 & & & 1,000 \\
\hline İşten Ayrılma Niyeti &,- 692 & ,029 &,- 771 & $-24,217$ &, 000 & 1,000 & 4,506 \\
\hline
\end{tabular}

\section{Sonuç}

Sosyal Değişim Teorisi ve İşle Bütünleşme Teorisine dayandırılan bu araştırmada otel çalışanlarının sosyal ve ekonomik değişim algılarının işten ayrılma niyetleri ve işe adanmışlıkları üzerindeki etkisi; işten ayrılma niyetlerinin işe adanmışlıkları üzerindeki etkisi ampirik olarak test edilmiştir. Araştırma sonuçları sosyal değişimin otel çalışanlarının işten ayrılma niyetlerini azalttığ 1 hipotezini desteklemektedir. Bu bulgu çalışanların çalışma arkadaşları ve yöneticileri ile adil bir değişim içerisinde olduğunu algılamaları halinde işten ayrılma niyetlerinin azaldığını belirleyen Biron ve Boon (2013) ve Osman vd. (2016) tarafından yapılan araştırma bulgularıyla örtüşmektedir. Ayrıca bu çalışmada sosyal değişimin çalışanların işe adanmışlıklarını artırdığı da belirlenmiştir. Bu bulgu da çalışanların sosyal değişime bağlı olarak çalışanların örgütleri tarafından desteklendiklerini algılamaları durumunda işe adanmışlıklarının arttığını belirleyen Muse ve
Stamper (2007) ve Muldoon (2017) tarafindan yapılan araştırma bulguları ile örtüşmektedir.

Sosyal değişimin işten ayrılma niyeti ve işe adanmışlık üzerindeki etkisine ilişkin bulgular çalışanların ilişki içerisinde olduğu çalışma arkadaşları ve yöneticileri tarafindan desteklendiklerini, çabalarının karşılığını aldıklarını düşünmeleri durumunda gönüllü işten ayrılma niyetlerinin azalacağını ve işlerine daha fazla yoğunlaşarak işe adanacaklarını göstermektedir. Otel yöneticileri çalışanların ilişkili olduğu insanlara karşı davranışlarını dikkate alan bir değerlendirme sistemi geliştirerek ve açık iletişim ile çalışanlara ilişkin değerlendirmelerini çalışanlarla paylaşarak, çalıșanlara gelișimi için firsat vererek ve çalıșanlarla ilgilenerek çalışanların işletme ile adil bir değişim içerisinde olduklarını düşünmelerini sağlayabilirler. Böylelikle çalışanların işten ayrılma niyetlerinin azalması ve işe adanmışlıklarının artırılması mümkün olabilecektir. 
Yapılan bu araştırma ekonomik değişimin otel çalışanlarının işten ayrılma niyetlerini arttırdığını göstermektedir. Çalışanların örgüt ile ilişkilerinde ekonomik değişimi esas almaları halinde örgütten gönüllü olarak ayrılma isteklerinin artacağına ilişkin bulgu, Shore vd. (2009) tarafindan yapılan araştırma bulguları ile örtüşmektedir. Ekonomik değişimin işten ayrılma niyetini artırdığ1 yönündeki bu bulgu otel çalışanları için ekonomik kazanımların işletmede gönüllü olarak çalışmak için yeterli olmadığını göstermektedir. Çalışanların işletme ile kurdukları ekonomik temelli ilişkilerin sonradan dahil olacağı işletmelerde de kurulabilmesi çalışanların işten gönüllü olarak ayrılma isteklerinin artmasina neden olabilmektedir. $\mathrm{Bu}$ etki Hezberg'in Çift Faktör Teorisine dayandırıldığında kurulan ekonomik ilişkinin işin doğasında var olan bir sağlık etmeni olarak değerlendirilmesi gerektiği, çalışanların işte kalma niyetlerini artırmak için ilişki temelli sosyal değişimin oluşturulması gerektiğ i söylenebilir. $\mathrm{Bu}$ nedenle otel yöneticilerinin ekonomik değişimin gerekli olduğu fakat çalışanların işten ayrılmalarını engellemek için yeterli olmadığını göz önünde bulundurarak ekonomik değişimi sosyal değişim ile desteklemeleri gerekmektedir.

$\mathrm{Bu}$ araştırmada, beklenildiği gibi, gönüllü olarak işten ayrılma niyetlerinin otel çalışanlarının ișe adanmışlığını azalttığı belirlenmiştir. Bu bulgu işten ayrılma niyetinin çalışanların işe adanmışlı̆̆ını azalttığını belirleyen Dane ve Brummel (2013), Micheal (2014) ve Meng ve Han (2014) tarafindan yapılan araştırma bulguları ile de örtüşmektedir. $\mathrm{Bu}$ bulguyu işten ayrılma niyetinde olan çalışanların işe yönelik katkılarının azaldığı şeklinde yorumlamak mümkündür. Olumsuz bir duygu ve düşünce olarak ortaya çıkan işten ayrılma niyetinin işe adanmışlık gibi çalışanların olumlu tutum ve davranışlarında azalmaya neden olduğu için otelcilik sektöründe yöneticilerin, çalışanların ișten ayrılma niyetinin oluşmasında etkili olan faktörleri (öncülleri) belirlemeye yönelik çaba sarf etmeleri gerektiği söylenebilir. Bunun için yöneticilerin çalışanlarla iletişim halinde olmaları ve çalışanları gözlemlemeleri, çalışanların davranışlarında ve performanslarındaki değişmeleri değerlendirmeleri yararlı olacaktır.

$\begin{array}{cclr}\text { Araştırma } & \text { sonuçları } & \text { genel } & \text { olarak } \\ \text { değerlendirildiğinde } & \text { sosyal } & \text { değişimin } & \text { otel }\end{array}$ çalışanlarının örgütte gönüllü olarak çalışmaya devam etmeleri ve işe adanmaları için ekonomik değişimden daha etkili olduğu görülmektedir. $\mathrm{Bu}$ nedenle ekonomik değișimin sosyal değișim gibi motive edici ve örgüte bağlayıcı bir unsur olmaktan uzaklaştığını söylemek mümkündür. Bu durumun ortaya çıkmasında çalışanların değişen özellikleri, kariyer beklentileri ve çevre şartlarının etkili olduğu düşünülmektedir.

\section{Sinırlılıklar ve yapılacak araştırmalar için öneriler}

$\mathrm{Bu}$ araştırmanın çeşitli sınırlılıkları vardır. En önemli sınırlılık araştırmanın düşük sezonda yapılması nedeniyle sadece Antalya'da bulunan sinırlı sayıdaki otel işletmelerinden veri toplanmış olmasıdır. $\mathrm{Bu}$ nedenle sonuç ve önerileri tüm otel çalışanlarına genellemek mümkün olmamıştır. Ayrıca araştırmada sadece işgörenlerden veri toplanması tek yönlü değerlendirmeye neden olmuştur. Yapılacak araştırmalarda hem işgörenlerden hem de yöneticilerinden veri toplanması daha sağlıklı sonuçlara ulaşılmasını sağlayabilir. Ayrıca yapılacak araştırmalarda departmanlara göre tabakalı örnekleme yapılarak departmanlar arasında karşılaştırma yapılabilir; sosyal ve ekonomik değişimin çalışanların işe gömülmüşlügüne etkisi belirlenebilir.

\section{Kaynakça}

Agarwal, U. A. (2014). Examining the impact of social Exchange relationships on innovative work behaviour: Role of work engagement. Team Performance Management, 20(3/4), 102-120.

Akgündüz, Y. ve Akdag, G. (2014). The effects of personality traits of employees on core self-evaluation and turnover intention. Çanakkale Onsekiz Mart Univ. J. Admin. Sci. 12 (24), 295-318.

Bhatnagar, J. (2012). Management of innovation: Role of psychological empowerment, work engagement and turnover intention in the Indian context. The International Journal of Human Resource Management, 23(5), 928-951.

Biron, M. ve Boon, C. (2013) Performance and turnover intentions: A social exchange perspective. Journal of Managerial Psychology, 28(5), 511-531.

Blau, P M. (1964). Exchange and power in social life. New York: Wiley.

Bock, G. W. ve Kim, Y. G. (2002). Breaking the myths of rewards: An exploratory study of attitudes about knowledge sharing. Information Resources Management Journal (IRMJ), 15(2), 14-21.

Brislin, R. W. (1970). Back-translationforcrossculturalresearch. Journal of Cross-Cultural Psychology, 1(3), 185-216.

Büyüköztürk, Ş. (2002). Faktör analizi: Temel kavramlar ve ölçek geliştirmede kullanımı. Kuram ve Uygulamada Eğitim Yönetimi, Güz(32): 470-483.

Choi, K. (2006). A structural relationship analysis of hotel employees' turnover intention. Asia Pacific Journal of Tourism Research, 11(4), 321-337.

Dane, E. ve Brummel, B. J. (2014). Examining workplace mindfulness and its relations to job performance and turnover intention. Human Relations, 67(1), 105-128.

Emerson, R. (1981). Social exchange theory. In M. Rosenberg \& R. Turner (Eds.), Social psychology: 
Sociological perspectives (pp. 30-65). New York: Basic Books.

Gefen, D. ve Ridings, C. M. (2002). Implementation team responsiveness and user evaluation of customer relationship management: A quasi-experimental design study of social exchange theory. Journal of Management İnformation Systems, 19(1), 47-69.

Gould-Williams, J. ve Davies, F. (2005). Using social exchange theory to predict the effects of HRM practice on employee outcomes: An analysis of public sector workers. Public Management Review, 7(1), 1-24.

Greene, J. V. (2012). Job embeddedness: Do the interaction effects of attitude, personality, and exchange relationships detract from performance?.Doctoral Dissertation, Kennesaw State University.

Hair, J. F. Jr., Black, W. C., Babin, B. J. ve Anderson, R. E. (2010). Multivariate data analysis (7th ed.). Upper Saddle River, NJ: PrenticeHall.

Harzer, C. ve Ruch, W. (2014). The role of character strengths for task performance, job dedication, interpersonal facilitation, and organizational support. Human Performance, 27(3), 183-205.

Homans, C. G. (1961). Social Behavior: Its Elementary Forms. New York: Harcourt, Brace\& World.

Jeong, M. ve Oh, H. (2017). Business-to-business social Exchange relationship beyond trust and commitment. International Journal of Hospitality Management, 65, 115-124.

Jiwen Song, L., Tsui, A. S. ve Law, K. S. (2009). Unpacking employee responses to organizational Exchange mechanisms: The role of social and economic Exchange perceptions. Journal of Management, 35(1), 56-93.

Kahn, W. A. (1990). Psychological conditions of personal engagement and disengagement at work. Academy of Management Journal, 33(4), 692-724.

Karatepe, O. M. ve Olugbade, O. A. (2009). The effects of job and personal resources on hotel employees' work engagement. International Journal of Hospitality Management, 28(4), 504-512.

Konovsky, M. A. ve Pugh, S. D. (1994). Citizenship behavior and social exchange. Academy of Management Journal, 37(3), 656-669.

Lavelle, J. J.,Rupp, D. E. ve Brockner, J. (2007). Taking a multifoci approach to the study of justice, social exchange, and citizenship behavior: The target similarity model. Journal of Management, 33(6), 841-866.

Lee, K. H., Choo, S. W. ve Hyun, S. S. (2016). Effects of recovery experiences on hotel employees' subjectivewell-being. International Journal of Hospitality Management, 52, 1-12.

Li, X., Sanders, K. ve Frenkel, S. (2012). How leadermember exchange, work engagement and HRM consistency explain Chinese luxury hotel employees' job performance. International Journal of Hospitality Management, 31(4), 1059-1066.

Liao, F. Y., Yang, L. Q., Wang, M., Drown, D. ve Shi, J. (2013). Team-member Exchange and work engagement:
Does personality make a difference?.Journal of Business and Psychology, 28(1), 63-77.

Lodahl, T.M. ve Kejner, M. (1965).The definition and measurement of job involvement. Journal of Applied Psychology, Vol. 49, February, pp. 24-33.

Loi, R., Mao, Y. ve Ngo, H. Y. (2009). Linking leadermember Exchange and employee work outcomes: The mediating role of organizational social and economic exchange. Management and Organization Review, 5(3), 401-422.

Meng, B. ve Han, H. (2014). The effects of empowerment on employee psychological outcomes in upscale hotels. Journal of Hospitality Marketing \& Management, 23(2), 218-237.

Michael, D. F. (2014). The impact of leader-member exchange, supportive supervisor communication, affective commitment, and role ambiguity on bank employees' turnover intentions and performance. International Journal of Business and SocialScience, $5(7)$.

Mobley, W. H. (1977). Intermediate linkages in the relationship between job satisfaction and employee turnover. Journal of Applied Psychology, 62(2), 237.

Molina, M. A. C., González, J. M. H., Florencio, B. P. ve González, J. L. G. (2014). Does the balanced score card adoption enhance the levels of organizational climate, employees' commitment, job satisfaction and job dedication?. Management Decision, 52(5), 983-1010.

Muldoon, J. (2017). The role of job dedication in organizational citizenship behavior performance. Management Research Review, 40(10), 1042-1057.

Muse, L.A. ve Stamper, C.L. (2007). Perceived organizational support: Evidence for a mediated association with work performance. Journal of Managerial Issues, 19(4), 517-535.

Osman, I., Noordin, F., Daud, N. ve Othman, M.Z. (2016). The dynamic role of social exchange and personality in predicting turnover intentions among professional workers. Procedia Economicsand Finance, 35, 541-552.

Saks, A. M. (2006). Antecedents and consequences of employee engagement. Journal of Managerial Psychology, 21(7), 600-619.

Shore, L. M., Tetrick, L. E., Lynch, P. ve Barksdale, K. (2006). Social and economic exchange: Construct development and validation. Journal of Applied Social Psychology, 36(4), 837-867.

Shore, L.M., Bommer, W.H., Rao, A.N. ve Seo, J. (2009). Social and economic exchange in the employeeorganization relationship; the moderating role of reciprocation wariness. Journal of Managerial Psychology, 24(8), 701-721.

Tett, R. P. ve Meyer, J. P. (1993). Job satisfaction, organizational commitment, turnover intention and turnover: Path analyses based on meta-analytic findings. Personnel Psychology, 46(2), 259-293.

Tracey, J. B. ve Hinkin, T. R. (2008). Contextual factors and cost profiles associated with employee turnover. Cornell Hospitality Quarterly, 49(1), 12-27. 
Van Scotter, J. R. (2000). Relationships of task performance and contextual performance with turnover, job satisfaction, and affective commitment. Human Resource Management Review, 10(1), 79-95.

Van Scotter, J. R. ve Motowidlo, S. J. (1996). Interpersonal facilitation and job dedication as separate facets of contextual performance. Journal of Applied Psychology, 81(5), 525-531.

Yang, J. T. (2008). Effect of new comersocialisation on organisational commitment, job satisfaction, and turnover intention in the hotel industry. The Service Industries Journal, 28(4), 429-443.

\section{Extended abstract in English}

Exchanges between individuals can be categorized as social and economic exchanges. Social exchange involves the exchange of socio-emotional resources based on trust whereas economic exchange involves the exchange of economic and materialistic sources (salary, bonus, promotion etc.) based on specific promises (Jiwen Song et al., 2009). Social exchange, includes interpersonal trust, exchange in specific issues and certain obligations (Emerson, 1981). Conversely, economic exchange based on transactional contracts which includes economic sources such as salary, bonus, promotion etc. (Konovsky and Pugh, 1994). Another variable in the study that job dedication is the willingness of an employee to make extra effort to successfully complete assigned tasks (Harzer and Ruch, 2014). If job dedication is high, this leads to positive disciplinary behaviour, such as obeying the rules, working hard and taking the initiative to solve problems (Van Scotter and Motowidlo, 1996). Turnover intention can be described as "the last in a sequence of withdrawal cognitions, a set to which thinking of quitting and intent to search for alternative employment also belongs" (Tett and Meyer, 1993).

The primary aim of this study is to the effect of the perceptions of hotel employees' social and economic exchange on their job dedication and turnover intention. It is also aimed to determine the effect of hotel employees' turnover intention on their job dedication in this research. In this context, questionnaire form was applied in January-March 2018 with convenience sampling method and 401 valid questionnaire forms were obtained. Data was collected from hotel employees in Antalya, Turkey. Standard scales were used, based on a 5-point Likert scale ranging from $1=$ Strongly Disagree to $5=$ Strongly Agree. Social and economic exchange were measured using the 6-item scales developed by Shore at al. (2006). Cronbach's $\alpha$ reliability values were 0.96 and 0.91 for the social exchange and economic exchange scales respectively. Job dedication was measured using the 3-item scale adopted by Lee et al. (2016) from Van Scotter and Motowidlo (1996) and Cichy et al. (2009). Cronbach's $\alpha$ reliability value for this scale was 0.90 . Turnover intention was measured using three items translated by Akgunduz and Akdag (2014) from Jung and Yoon (2013). Cronbach's $\alpha$ reliability value for this scale was 0.97 .

The sample was composed of 65 per cent males and 35 per cent females. The largest group of respondents was between 18 and 24 years old (51 per cent). Respondents' education level was mostly 'graduate degree" (52 per cent), and most of they are mostly temporary employees (61 per cent). Most respondents have served in the tourism industry for 5 years and under ( 55 per cent) and they have worked in the same hotel for 5 years and under (93 per cent). The first hypothesis, that social exchange would positively affect their job dedication, was supported, in that employees with stronger social exchange reported stronger positive job-oriented attitudes. The study's second hypothesis, that social exchange would negatively affect employees' turnover intention, was supported. The third hypothesis, that economic exchange would negatively affect their job dedication, was not supported. That is, economic support did not increase employees' job dedication. The fourth hypothesis, that economic exchange would negatively affect employees' turnover intention, was supported. The fifth hypothesis, that employees' turnover intention would negatively affect employees' job dedication, was supported. Findings about the affect of social exchange on the employees' turnover intention and job dedication show that employees are supported by their colleagues and managers is reduced their turnover intention and that social exchange can increase hotel employees' job dedication. From the organization's perspective, when social exchange between employee and organization is perceived as fair by employees, employees' positive attitudes and behaviour increase, such as job dedication. Hotel managers can develop mutual trust and justice to increase positive social exchange in their practices. Hotel managers can also invest in employees, and provide training and development opportunities to increase positive social exchange in the minds of employees. 